\title{
SIK2 wt Allele
}

National Cancer Institute

\section{Source}

National Cancer Institute. SIK2 wt Allele. NCI Thesaurus. Code C92519.

Human SIK2 wild-type allele is located in the vicinity of 11 q23.1 and is approximately 128

$\mathrm{kb}$ in length. This allele, which encodes serine/threonine-protein kinase SIK2 protein, is involved in the modulation of both mitotic spindle formation and insulin-mediated signaling. 